\title{
Air quality and meteorological patterns of an early spring heatwave event in an industrialized area of Attica, Greece
}

\author{
Anastasios Mavrakis $^{1}$ [D $\cdot$ Athanasia Kapsali ${ }^{2} \cdot$ Ioannis X. Tsiros $^{3} \cdot$ Katerina Pantavou $^{3}$
}

Received: 20 September 2020 / Accepted: 18 December 2020

(c) Springer Nature Switzerland AG 2021

\begin{abstract}
Heatwaves—excessively hot ambient conditions that are considered a serious threat to human health—are often associated with poor air quality. The aim of this study was to examine the impact of an early heatwave episode in an industrialized plain in the eastern Mediterranean region (Thriasio, Greece) on human thermal discomfort and urban air quality. The heatwave occurred in mid (15-20) May 2020, shortly after some of the restrictions that were improsed to halt the spread of coronavirus disease 2019 (COVID-19) in Greece were lifted (on 4 May). The discomfort index (DI) and the daily air quality index (DAQI) were calculated on an hourly basis throughout spring 2020 (March, April, May) using data from two stations that measure meteorological parameters and air pollutant concentrations in the Thriasio Plain. The analysis showed that the air temperature increased during 7-17 May to levels that were more than $10^{\circ} \mathrm{C}$ above the monthly average value $\left(25.8^{\circ} \mathrm{C}\right)$. The maximum measured air temperature was $38^{\circ} \mathrm{C}$ (on 17 May). The results showed a high level of thermal discomfort. The DI exceeded the threshold of $24^{\circ} \mathrm{C}$ for several hours during 13-20 May. Increased air pollution levels were also identified. The average DAQI was estimated as $0.83 \pm 0.1$ and $1.14 \pm 0.2$ at two monitoring stations in the region of interest during the heatwave. Particulate matter (diameter $<10 \mu \mathrm{m}$ ) appeared to contribute significantly to the poor air quality. Significant correlations between the air temperature, DI, and AQSI were also identified.
\end{abstract}

Keywords Heatwave $\cdot$ Air quality index $\cdot$ Thermal discomfort

\section{Introduction}

Globally, heatwaves are getting hotter, longer, and more frequent, particularly in regions affected the most by climate change. Moreover, these heatwave trends are accelerating (Perkins-Kirkpatrick and Lewis 2020). For instance, in the

Communicated by Katerina Pantavou, Guest Editor and Georgios K. Nikolopoulos, Chief Editor.

Topical Collection: Health Risks from Infectious Diseases in a Changing Mediterranean Environment.

Anastasios Mavrakis

mavrakisan@yahoo.gr

1 Environmental Education, West Attica Secondary Education Directorate, Greek Ministry of Education, I. Dragoumi 24 str, 19200 Elefsina, Greece

2 Department of Physics, National and Kapodistrian University of Athens, Athens, Greece

3 Laboratory of General and Agricultural Meteorology, Agricultural University of Athens, Athens, Greece
Mediterranean Basin, heatwave frequency increased by two days per decade from 1950 to 2017 , and by 6.4 days per decade from 1980 to 2017 (Perkins-Kirkpatrick and Lewis 2020).

Extreme temperature events have a major impact on various aspects of human life, especially when these events are unexpected (Fontana et al. 2015; Sailor et al. 2019). Extreme temperatures may cause wildfires (Mavrakis and Salvati 2015) and marine heatwaves (Mavrakis and Tsiros 2018), can increase the energy demand for cooling (Añel et al. 2017) and affect productivity (Xia et al. 2018), are directly linked to loss of life (Xu et al. 2016), and indirectly affect the prevalence of infectious diseases (Naval et al. 2017). Several studies have examined heatwave and drought events through a unified approach (Mavrakis et al. 2015b, 2016). In many cases, these two environmental hazards are related, so it can be unclear whether effects of such events on human well-being are due to a short-duration heatwave or a longer-term drought. Previous studies focusing on the Thriasio Plain suggest that the local climatic regime has become warmer and drier (Mavrakis et al. 
2015a, 2015b, 2016). This represents an emblematic example of the urban-rural relationship.

The Thriasio Plain is located close to the city of Athens- the capital of Greece and the main industrial hub of the country. This plain has the highest industrial activity, fuel consumption, and industrial pollution levels in Greece (Mavrakis et al. 2008). The region is characterized by the spontaneous development of various sectors, including residential areas, agriculture, and a range of industries such as oil refineries and the steel, steelworking, chemical, product, nonmetal mineral material, and cement industries. There are nine large quarries on the mountains surrounding the plain. The seashore is occupied by various industries that are performing a variety of activities (both legislated and unlegislated). The 13 port facilities of Elefsis Harbor handle 5500 ships per year and a total cargo load that is 2.5 times larger than that handled by Piraeus Harbor. All of these activities coexist within the same environment, with the road network (three freeways) and two rail networks crossing the urban poles in this region (Mavrakis et al. 2016, 2020; Cecchini et al. 2019).

During 15-20 May 2020, Greece experienced the earliest heatwave ever recorded in the country according to the criteria of Metaxas and Kallos (1980). The air temperature during the heatwave exceeded the highest value that had been recorded during the second ten-day period of May $\left(35.8{ }^{\circ} \mathrm{C}\right.$ in 11 th May 2003) for over 150 years, according to the historical climatic archive of the National Observatory of Athens (Founda 2020). The Thriasio Plain is particularly vulnerable to temperature extremes. When combined with poor air quality due to the intense industrial activity in the area, these temperature extremes can cause unfavorable environmental conditions for human health (Theoharatos et al. 2010; Mavrakis et al. 2012).

In the present study, we examined the thermal and air quality conditions in the Thriasio Plain during the heatwave experienced in Greece during 15-20 May 2020. Two commonly used indices, the discomfort index (DI) and the daily air quality (stress) index (DAQI), were estimated. This early heatwave occurred shortly after some of the restrictions that were imposed to halt the spread of coronavirus disease 2019 (COVID-19) in Greece were lifted (on 4 May 2020), when the process of gradually restoring normal industrial and transportation activities in the area began. The results of this study can be used by policy makers to formulate appropriate resilience measures that support the health of the population during heatwaves (McElroy et al. 2020).

\section{Materials and methods}

\section{Study area}

Greece has a Mediterranean climate (Kottek et al. 2006). The warmest months are July and August (the mean maximum temperature ranges between $29^{\circ} \mathrm{C}$ and $35^{\circ} \mathrm{C}$; HNMS 2020). Spring (March-May) is short (HNMS 2020). In Athens, the monthly mean maximum temperature in May has increased by about $0.2{ }^{\circ} \mathrm{C}$ per decade over the last 130 years (Founda 2020). The highest monthly mean maximum temperature recorded was $29^{\circ} \mathrm{C}$ (in 1945), followed by $28.8^{\circ} \mathrm{C}$ (in 2003). The lowest monthly mean maximum temperature was $20.2{ }^{\circ} \mathrm{C}$ (in 1919; Founda 2020). Based on data recorded at the Thissio Climatic Station of the National Observatory of Athens (NOA) from 1860 onwards, the highest hourly maximum temperature $\left(37.6^{\circ} \mathrm{C}\right)$ was recorded on 29 May 2008. Hourly maximum temperatures of over $35^{\circ} \mathrm{C}$ have been recorded on a total of 16 days, all of which were in late May except for a temperature of $35.8^{\circ} \mathrm{C}$ recorded on 11 May 2003. Hourly maximum temperatures of over $36^{\circ} \mathrm{C}$ have been recorded on four days in late May (25 May 1945, 29 May 1950, 26 May 1994, 29 May 2008).

In mid (15-20) May 2020, Greece experienced a heatwave with extremely high temperatures $\left(39-40{ }^{\circ} \mathrm{C}\right)$; indeed, it set many maximum temperature records (HNMS 2020; Vougioukas et al. 2020). In Athens, the highest air temperature $\left(37^{\circ} \mathrm{C}\right.$, Thissio Station) was recorded on 16 and 17 May 2020, which was the highest in the last 160 years for mid-May (Founda 2020). At the same time, a low-intensity but long-duration dust transport episode from Africa was recorded.

The Thriasio Plain (Fig. 1) extends over an area of $120 \mathrm{~km}^{2}$ in the prefecture of Western Attica, northwest of Greater Athens. There are three municipalities in the Thriasio Plain: Elefsis, Aspropyrgos, and Mandra, with a resident population of 78,038 according to the 2011 census (HSA 2020). The Thriasio Plain has a smooth surface morphology that is slightly inclined towards the sea (3\%) and is surrounded by areas with high relief. Its close proximity to the sea and the local climatic conditions produce local regressive atmospheric circulation patterns that greatly inhibit atmospheric self-cleaning through dispersion and transport mechanisms. Air temperature inversion heights are especially low during the cold period of the year; they are frequently lower than the surrounding hills and comparable to the heights of the highest chimneys of the large industrial complexes. Thus, air pollutants can be trapped within a shallow layer, resulting in high (daily and hourly) pollution concentrations (Lykoudis et al. 2008; Mavrakis et al. 2008, 2015b; Toumpos et al. 2017).

\section{Data sources}

Hourly values of the air temperature $\left(T_{\mathrm{a}},{ }^{\circ} \mathrm{C}\right)$, the relative humidity (RH, \%), and the concentrations of sulfur dioxide $\left(\mathrm{SO}_{2}\right)$, nitrogen dioxide $\left(\mathrm{NO}_{2}\right)$, ozone $\left(\mathrm{O}_{3}\right)$, and particulate matter less than $10 \mu \mathrm{m}$ in diameter $\left(\mathrm{PM}_{10}\right)$ for the time period between 1 March and 31 May 2020 were used in this 
Fig. 1 Map of Attica Prefecture

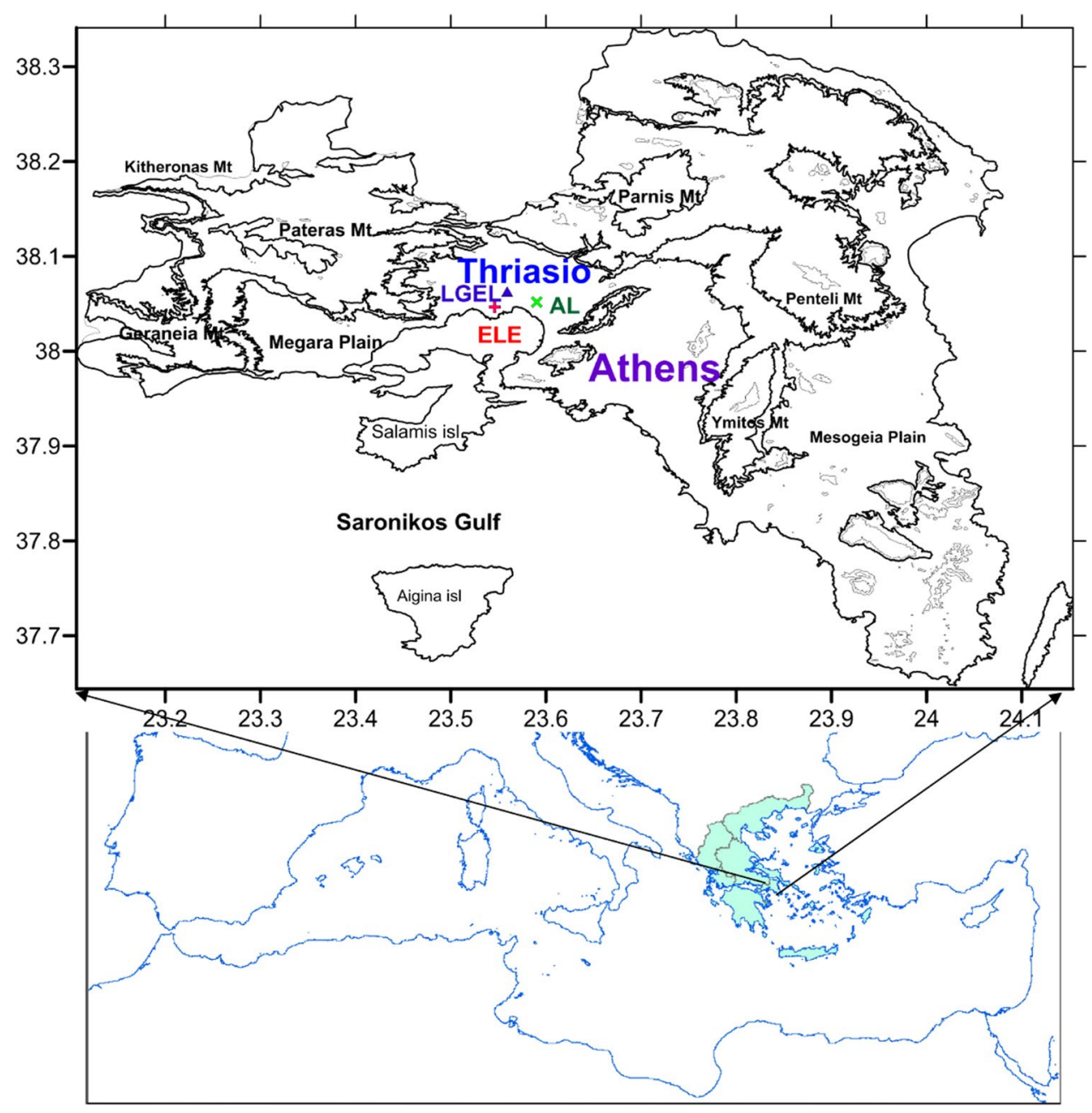

study. These data were obtained from the meteorological stations in Elefsis Air Base (LGEL), Elefsis City (ELE), and Alonistra (AL). LGEL is operated by the Hellenic National Meteorological Service (HNMS), World Meteorological Organization (WMO) code LGEL (167180). ELE is located in the center of Elefsis City (1000 m from the seashore), away from large constructions. It is operated by the Bureau of Pollution for the Municipality of Elefsis, and provides air quality data $\left(\mathrm{NO}_{2}, \mathrm{O}_{3}, \mathrm{PM}_{10}\right)$. AL is located in Aspropyrgos (500 m south of the city center and $1000 \mathrm{~m}$ from the seashore). It is operated by the Bureau of the Environment for the Municipality of Aspropyrgos (BEMA), and provides air quality $\left(\mathrm{SO}_{2}, \mathrm{NO}_{2}, \mathrm{O}_{3}, \mathrm{PM}_{10}\right)$ and meteorological $\left(T_{\mathrm{a}}\right.$, $\mathrm{RH})$ data.

\section{Assessment of the thermal conditions and air quality}

Thermal conditions were assessed using the discomfort index (DI, ${ }^{\circ} \mathrm{C}$; Thom 1959), which was estimated based on
Table 1 Assessment scale for the discomfort index (DI; Giles et al. 1990) and the daily air quality index (DAQI; Katsoulis and Kassomenos 2004)

\begin{tabular}{llll}
\hline DI $\left({ }^{\circ} \mathrm{C}\right)$ & Thermal conditions & DAQI & Air quality \\
\hline $18-21$ & No discomfort & $<0.2$ & Very low \\
$21-24$ & $<50 \%$ of the population feels discomfort & $0.2-0.4$ & Low \\
$24-26$ & $>50 \%$ of the population feels discomfort & $0.4-0.6$ & Moderate \\
$27-29$ & Most of the population suffers discomfort & $0.6-0.8$ & Distinct \\
$29-32$ & Everyone feels severe stress & $>0.8$ & Strong \\
Over 32 & State of medical emergency & Independent of & Extreme \\
& & DAQI & \\
\hline
\end{tabular}


an equation in Paliatsos and Nastos (1999), modified for Greece:

$\mathrm{DI}=T_{\mathrm{a}}-0.55 \cdot(1-0.01 \cdot R H) \cdot\left(T_{\mathrm{a}}-14.5\right)$,

where $T_{\mathrm{a}}$ is the dry bulb temperature $\left({ }^{\circ} \mathrm{C}\right)$ and $\mathrm{RH}$ is the relative humidity (\%). The DI categorizes thermal environments into levels of thermal discomfort according to the assessment scale presented in Table 1.

Air quality was assessed based on the daily air quality index (DAQI). The DAQI is a measure of the air quality and the health risk from air pollution that is derived from the average daily concentration of air pollutants using the following formula (Matzarakis and Mayer 1991; Kassomenos et al. 2004; Katsoulis and Kassomenos 2004):

$\mathrm{DAQI}=\sum_{i=1}^{4} \frac{\text { average daily value }}{\text { MI-24 } \mathrm{h} \text { value }}$

where $i$ is the air pollutant under consideration $\left(\mathrm{SO}_{2}, \mathrm{NO}_{2}\right.$, $\mathrm{O}_{3}$, or $\mathrm{PM}_{10}$ ) and "MI-24 h value" is the threshold concentration of that air pollutant according to European Community standards (hourly $\mathrm{SO}_{2}: 350 \mu \mathrm{g} / \mathrm{m}^{3}$; hourly $\mathrm{NO}_{2}: 200 \mu \mathrm{g}$ / $\mathrm{m}^{3}$; mean 8-hourly $\mathrm{O}_{3}: 180 \mu \mathrm{g} / \mathrm{m}^{3}$; daily $\mathrm{PM}_{10}: 50 \mu \mathrm{g} / \mathrm{m}^{3}$ ). Values were calculated for hourly data, which were then used to derive daily averages. The assessment scale for the DAQI is presented in Table 1.

\section{Statistical analysis}

Pearson's correlation test was applied to examine the possible relationships between air temperature, relative humidity, air pollutant concentrations, DI, and DAQI. The confidence level was set at 0.05 .

\section{Results}

The average monthly $T_{\mathrm{a}}$ varied between $13.1{ }^{\circ} \mathrm{C}$ and $21.8^{\circ} \mathrm{C}$ during the period from 1 March to 31 May 2020 in the Thriassio Plain (Table 2). The estimated monthly $T_{\mathrm{a}}$ values from the AL station were slightly higher than those from the LGEL station. The hourly air temperature ranged between $3{ }^{\circ} \mathrm{C}$ and $38^{\circ} \mathrm{C}$.

Rapid increases in the mean daily air temperature, from $16.7{ }^{\circ} \mathrm{C}$ to $28.7{ }^{\circ} \mathrm{C}$ at the LGEL station and from $18.3{ }^{\circ} \mathrm{C}$ to $28.6^{\circ} \mathrm{C}$ at the $\mathrm{AL}$ station, were observed between 7 May and 17 May. The maximum daily $T_{\mathrm{a}}$ occurred on 16 and 17 May at both LGEL $\left(38{ }^{\circ} \mathrm{C}\right.$ on both days) and $\mathrm{AL}\left(35.1{ }^{\circ} \mathrm{C}\right.$ and $36.1{ }^{\circ} \mathrm{C}$, respectively); see Fig. $2 \mathrm{a}$. On each day, $T_{\mathrm{a}}$ exceeded the threshold of $36{ }^{\circ} \mathrm{C}$ for four consecutive hours (from 12:00 to 16:00 LST) at LGEL. On 17 May, $T_{\mathrm{a}}$ was $38{ }^{\circ} \mathrm{C}$ for four consecutive hours at LGEL, while the daily range of $T_{\mathrm{a}}$ was $20^{\circ} \mathrm{C}$ (minimum $T_{\mathrm{a}}=18{ }^{\circ} \mathrm{C}$ ). At $\mathrm{AL}, T_{\mathrm{a}}$ reached its maximum value $\left(36.1^{\circ} \mathrm{C}\right)$ for $1 \mathrm{~h}$ at 15:00 LST.

The average daily DI ranged between $13.1{ }^{\circ} \mathrm{C}$ and $19.5^{\circ} \mathrm{C}$. The DI values indicated that conditions leading to thermal discomfort ( $\mathrm{DI} \geq 24^{\circ} \mathrm{C}$ ) were present between 13 and 20 May 2020 (Fig. 2b), mainly during the hours immediately after midday (12:00 to 16:00 LST). Conditions leading to discomfort $\left(24.1{ }^{\circ} \mathrm{C}\right.$ to $\left.25.9^{\circ} \mathrm{C}\right)$ were also noted during the early evening hours (17:00 to 20:00 LST) at AL. A DI value of $>26^{\circ} \mathrm{C}$ occurred each day from 16 to 20 May at LGEL. The maximum DI was recorded at 15:00 LST on 17 May at both LGEL $\left(27.1^{\circ} \mathrm{C}\right)$ and $\operatorname{AL}\left(26.3^{\circ} \mathrm{C}\right)$ (Fig. 2b).

$\mathrm{SO}_{2}, \mathrm{NO}_{2}, \mathrm{O}_{3}$, and $\mathrm{PM}_{10}$ reached their maximum concentrations during the heatwave (Fig. 3a and b). The maximum daily concentration of $\mathrm{SO}_{2}\left(123 \mu \mathrm{g} / \mathrm{m}^{3}\right)$ was recorded on 19 May (Fig. 3a), and the maximum daily concentration of $\mathrm{NO}_{2}$ ranged between $99 \mu \mathrm{g} / \mathrm{m}^{3}$ (20 May) and $160 \mu \mathrm{g} / \mathrm{m}^{3}$ (16 May) at AL (Fig. 3a) and between $164 \mu \mathrm{g} / \mathrm{m}^{3}$ (20 May) and $345 \mu \mathrm{g} / \mathrm{m}^{3}$ (16 May) at ELE station. The maximum daily concentration of $\mathrm{O}_{3}$ varied between $113 \mu \mathrm{g} / \mathrm{m}^{3}$ (20 May) and $219 \mu \mathrm{g} / \mathrm{m}^{3}$ (18 May) at AL, and between $84 \mu \mathrm{g} / \mathrm{m}^{3}$ (20 May) and $156 \mu \mathrm{g} / \mathrm{m}^{3}$ (17 May) at ELE. The maximum daily concentration of $\mathrm{PM}_{10}$ ranged from $156 \mu \mathrm{g} / \mathrm{m}^{3}$ (15 May) to $295 \mu \mathrm{g} / \mathrm{m}^{3}$ (20 May) at AL (Fig. 3a), and from $93 \mu \mathrm{g} / \mathrm{m}^{3}$ (16 May) to $493 \mu \mathrm{g} / \mathrm{m}^{3}$ (17 May) at ELE (Fig. 3b). The mean $\mathrm{PM}_{10}$ concentration was $90 \pm 41 \mu \mathrm{g} / \mathrm{m}^{3}$ and $72 \pm 44 \mu \mathrm{g} / \mathrm{m}^{3}$ at AL and ELE, respectively (Table 2).

The daily air quality index (DAQI) was estimated using the concentrations of $\mathrm{SO}_{2}, \mathrm{NO}_{2}, \mathrm{O}_{3}$, and $\mathrm{PM}_{10}$ recorded at ELE and AL (Table 2). The highest estimated average monthly DAQI occurred in May (0.82 at ELE). The estimated average DAQI was below 0.5 during the lockdown and 0.83 at AL and 1.14 at ELE during the heatwave (15-20 May). Figure $2 b$ shows that poor air quality was present during the latter period, with DAQI values exceeding the threshold of 0.8 (strong health risk) for several days. The maximum daily DAQI value reached 1.39 at ELE and 0.94 at AL (18 May). The mean daily DAQI value exceeded the threshold of 0.8 at both ELE and AL during the heatwave.

Correlations between the meteorological and air pollution parameters were analyzed using data from the stations in the region of interest, based on Pearson's linear correlation coefficients (Table 3). A significant positive correlation was found between $T_{\mathrm{a}}$ and DI; the estimated correlation coefficients ranged between 0.75 and 1.0. RH and DI were negatively correlated, with correlation coefficients ranging between -0.49 and -0.55 . A significant relationship was identified between DI and DAQI; the estimated coefficients varied between 0.57 and 0.82 . The $\mathrm{PM}_{10}$ concentration showed the strongest correlation with DAQI (correlation coefficients: $0.84-1.00$ ). 


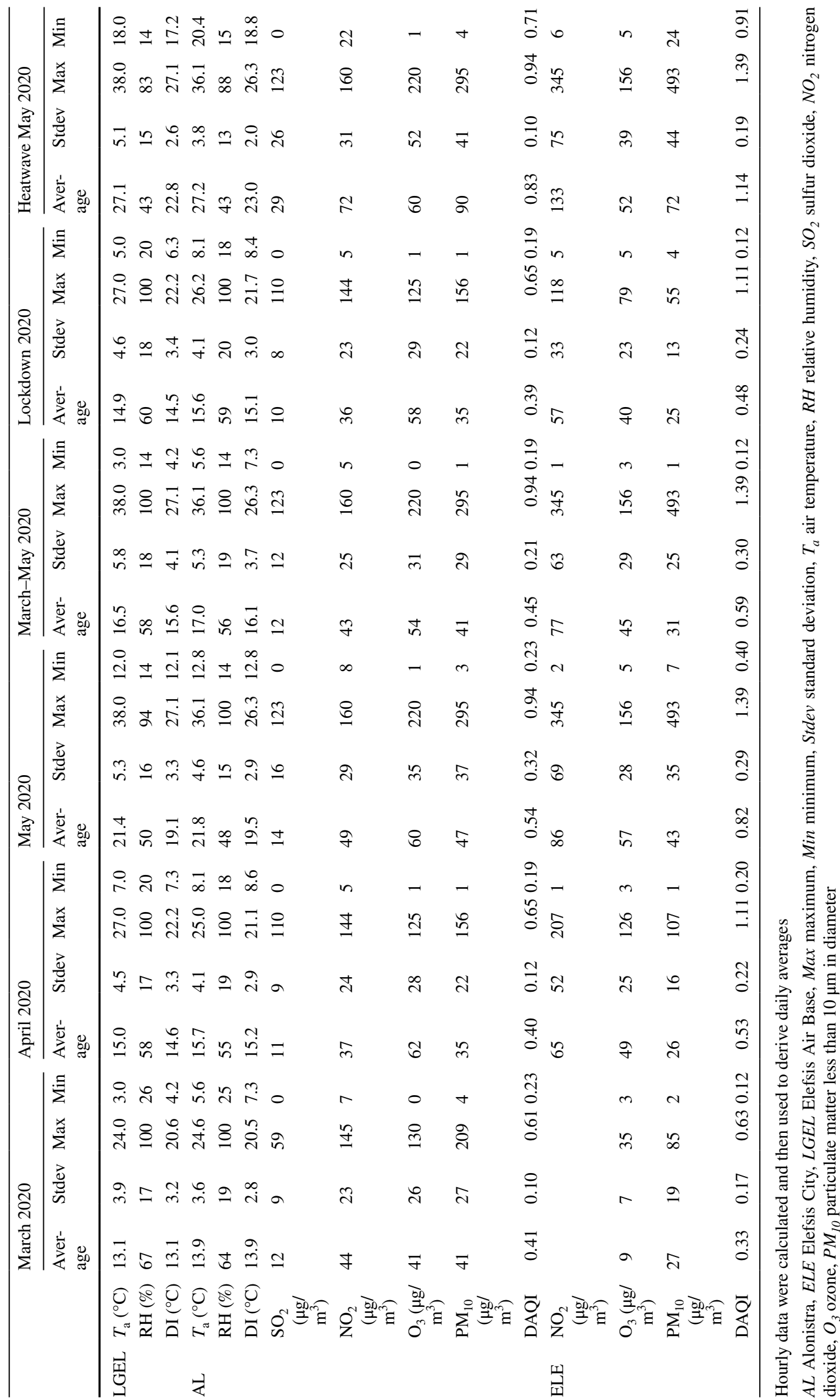


Fig. 2 Variation in a the maximum daily air temperature and $\mathbf{b}$ the maximum discomfort index (DI) and daily air quality index (DAQI) values
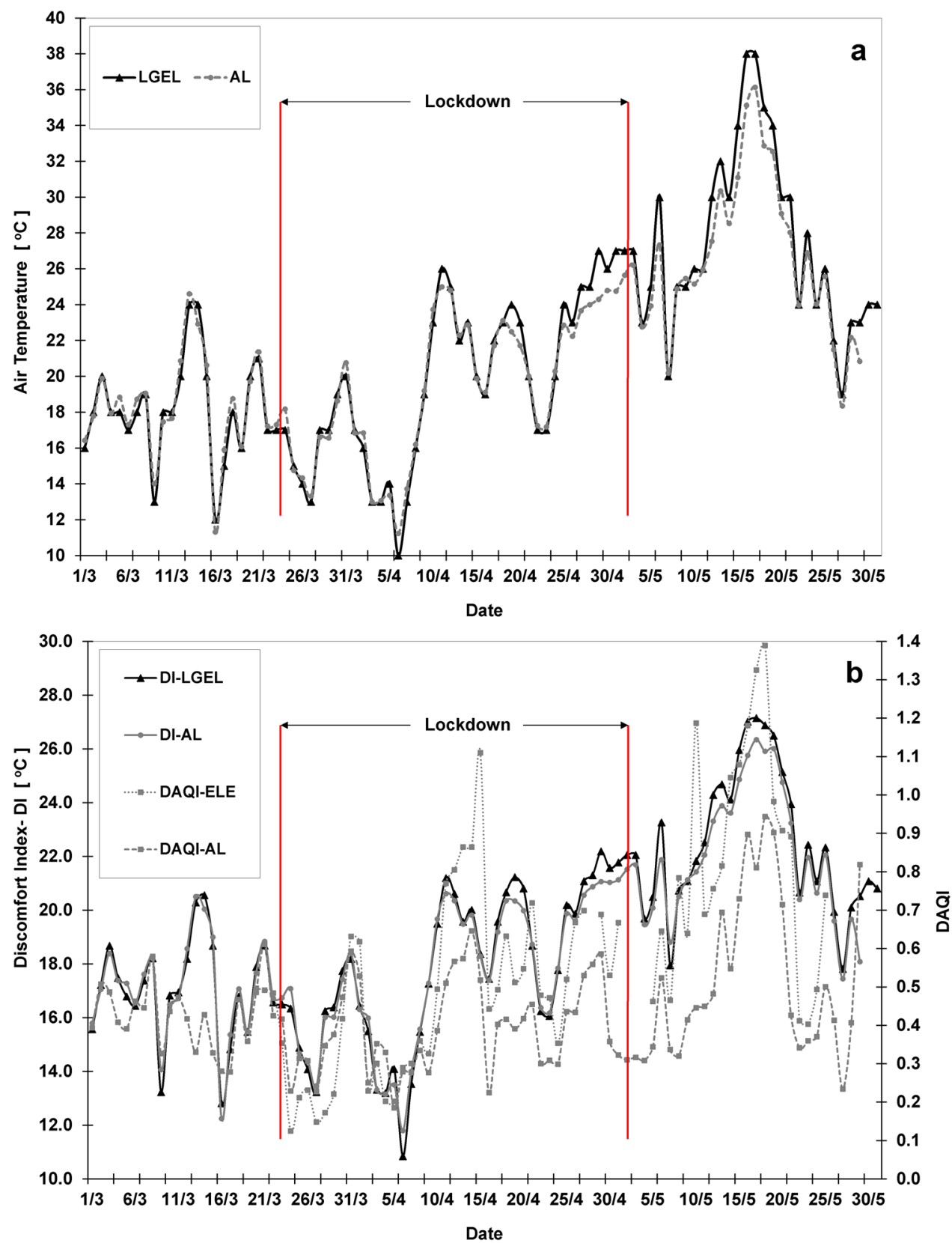

\section{Discussion}

The present study examined the thermal conditions and air quality during the spring of 2020 in an industrialized plain in Attica, Greece. This period was marked by the imposition of restrictions aimed at suppressing the spread of COVID19 and the subsequent gradual easing of these restrictions in mid-May, which coincided with an early heatwave. The maximum air temperature during the heatwave was more than $10{ }^{\circ} \mathrm{C}$ above the monthly normal climatic average $\left(25.8^{\circ} \mathrm{C}\right.$, LGEL station; HNMS 2020). The results showed a high level of thermal discomfort and poor air quality. Significant correlations between the air temperature, DI, and
DAQI were identified. DAQI was strongly correlated with $\mathrm{PM}_{10}$ concentration, indicating that the $\mathrm{PM}_{10}$ concentration is an important influence on air quality.

Heatwaves are associated with the large-scale circulation of air masses in the upper atmosphere, as this circulation favors the occurrence of such phenomena. Depending on the season, the subtropical jet stream plays a crucial role in heatwave generation at northern latitudes, such as the 2018 and 2019 heatwaves in Central and Northern Europe, because it transports hot air masses at these latitudes. The early heatwave in May seems to have occurred due to an unusually early shift of the jet stream to northern latitudes (above the northern border of Greece), leading to the 
Fig. 3 Variation in the daily maximum concentrations of air pollutants at a Alonistra station (AL) and $\mathbf{b}$ Elefsis station (ELE)
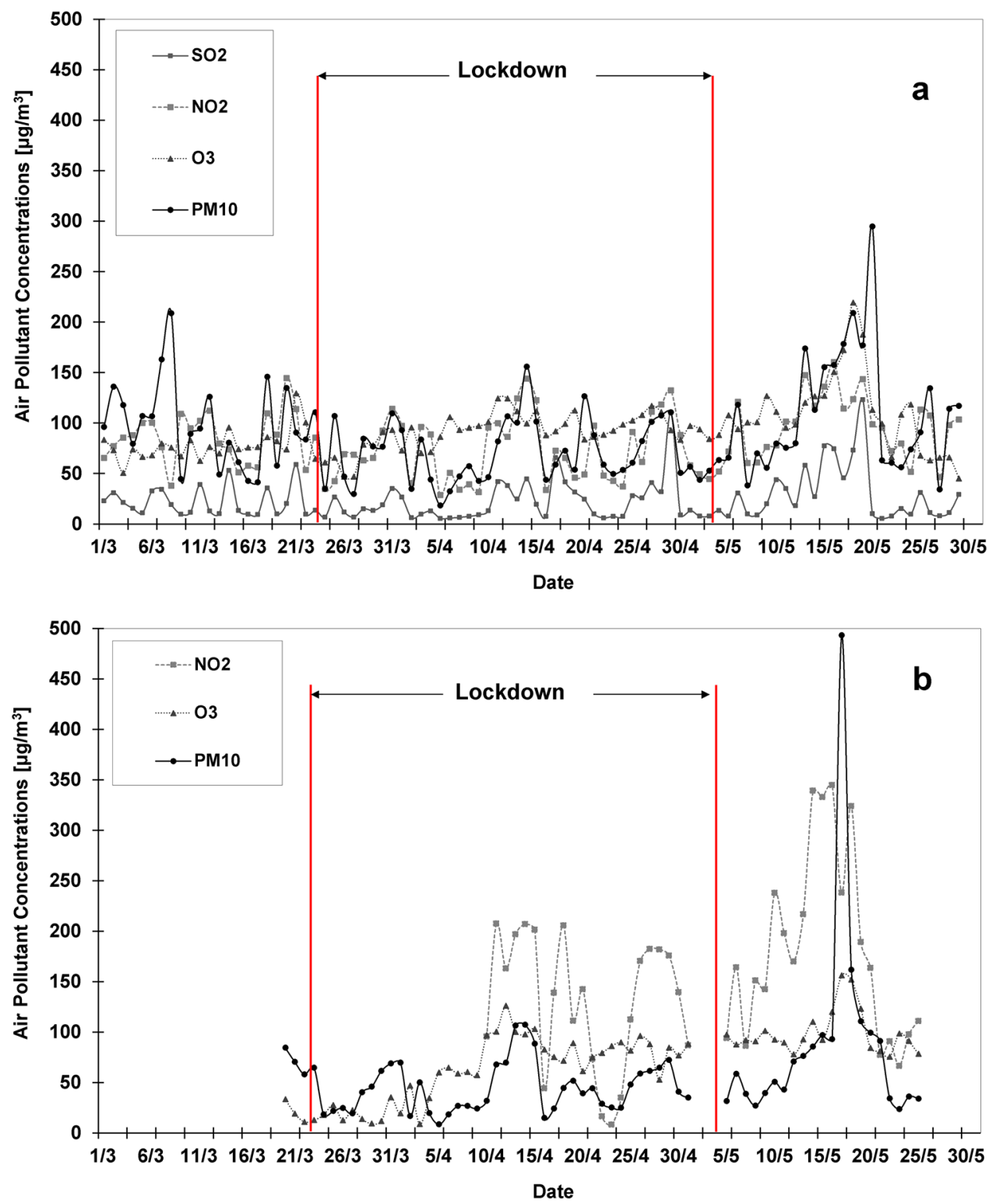

circulation and transportation of very hot air masses from North Africa, as documented in previous studies (Flocas et al. 2009; Theoharatos et al. 2010; Mavrakis and Tsiros 2018). Figure 4 shows the results of back-trajectory analysis of the air masses using the FLEXTRA model. This model uses meteorological data provided by ECMWF (the European Centre for Medium-Range Weather Forecasts) (www. nilu.no/trajectories; Stohl 1998). The results show the flow of air masses from the Sahara Desert and their circulation above the central Mediterranean Sea and Greece during the aforementioned time period. The circulation of hot, dry air masses above the Mediterranean Sea humidified the masses (Theoharatos et al. 2010). At the same time, due to the low speed of the wind above the sea, the sea surface temperature increased, yielding a marine heatwave event, in agreement with Mavrakis and Tsiros (2018). Also, according to Table 3, the $\mathrm{PM}_{10}$ values were strongly correlated with the DAQI values. This is an indication that the high $\mathrm{PM}_{10}$ concentrations are due to a Sahara dust transport episode. The calm conditions in the area favored high $\mathrm{PM}_{10}$ concentrations and prevented the dispersion of particulates.

The abrupt increases in the air temperature, DI, DAQI, and $\mathrm{PM}_{10}$ came soon after a lockdown period lasting almost two months (from 23 March to 4 May 2020) that was prompted by the COVID-19 pandemic (Fig. 2). This lockdown was implemented despite being strongly criticized (Ioannidis et al. 2020). During the lockdown, the values of both DI and DAQI were relatively low according to all of the criteria mentioned above. The early spring heatwave led to abrupt increases in DI and DAQI (i.e., 
Table 3 Pearson correlation coefficients for the associations between air temperature $\left(T_{\mathrm{a}}\right.$ ), relative humidity (RH), air pollutant concentrations $\left(\mathrm{SO}_{2}, \mathrm{NO}_{2}, \mathrm{O}_{3}, \mathrm{PM}_{10}\right)$, discomfort index (DI), and daily air quality index (DAQI)

\begin{tabular}{|c|c|c|c|c|c|c|c|c|c|c|c|c|c|c|c|c|}
\hline \multirow[t]{2}{*}{ Station } & & \multicolumn{3}{|l|}{ LGEL } & \multicolumn{8}{|l|}{$\mathrm{AL}$} & \multicolumn{4}{|l|}{ ELE } \\
\hline & & $\mathrm{Ta}$ & RH & DI & $\mathrm{Ta}$ & RH & DI & $\mathrm{SO}_{2}$ & $\mathrm{NO}_{2}$ & $\mathrm{O}_{3}$ & $\mathrm{PM}_{10}$ & DAQI & $\mathrm{NO}_{2}$ & $\mathrm{O}_{3}$ & $\mathrm{PM}_{10}$ & DAQI \\
\hline \multirow[t]{3}{*}{ LGEL } & $T_{\mathrm{a}}$ & 1 & & & & & & & & & & & & & & \\
\hline & RH & -0.58 & 1 & & & & & & & & & & & & & \\
\hline & DI & 1.00 & -0.57 & 1 & & & & & & & & & & & & \\
\hline \multirow[t]{8}{*}{ AL } & $T_{\mathrm{a}}$ & 0.99 & -0.59 & 0.99 & 1 & & & & & & & & & & & \\
\hline & RH & -0.50 & 0.91 & -0.50 & -0.49 & 1 & & & & & & & & & & \\
\hline & DI & 0.99 & -0.57 & 0.99 & 1.00 & -0.49 & 1 & & & & & & & & & \\
\hline & $\mathrm{SO}_{2}$ & 0.45 & -0.18 & 0.42 & 0.45 & -0.23 & 0.43 & 1 & & & & & & & & \\
\hline & $\mathrm{NO}_{2}$ & 0.45 & -0.08 & 0.42 & 0.45 & -0.13 & 0.43 & 0.68 & 1 & & & & & & & \\
\hline & $\mathrm{O}_{3}$ & 0.27 & -0.57 & 0.28 & 0.29 & -0.45 & 0.29 & -0.19 & -0.53 & 1 & & & & & & \\
\hline & $\mathrm{PM}_{10}$ & 0.56 & -0.10 & 0.54 & 0.56 & -0.14 & 0.56 & 0.69 & 0.72 & -0.17 & 1 & & & & & \\
\hline & DAQI & 0.59 & -0.15 & 0.57 & 0.60 & -0.18 & 0.59 & 0.70 & 0.72 & -0.12 & 1.00 & 1 & & & & \\
\hline \multirow[t]{4}{*}{ ELE } & $\mathrm{NO}_{2}$ & 0.63 & -0.22 & 0.60 & 0.61 & -0.18 & 0.59 & 0.66 & 0.86 & -0.43 & 0.74 & 0.75 & 1 & & & \\
\hline & $\mathrm{O}_{3}$ & 0.44 & -0.62 & 0.46 & 0.45 & -0.58 & 0.47 & 0.02 & -0.11 & 0.70 & -0.03 & 0.01 & -0.68 & 1 & & \\
\hline & $\mathrm{PM}_{10}$ & 0.67 & -0.29 & 0.66 & 0.68 & -0.30 & 0.67 & 0.50 & 0.63 & 0.05 & 0.85 & 0.86 & 0.55 & 0.08 & 1 & \\
\hline & DAQI & 0.82 & -0.46 & 0.81 & 0.82 & -0.45 & 0.82 & 0.59 & 0.69 & 0.16 & 0.84 & 0.86 & 0.75 & 0.30 & 0.92 & 1 \\
\hline
\end{tabular}

Statistically significant coefficients are shown in bold

$A L$ Alonistra, ELE Elefsis City, $L G E L$ Elefsis Air Base, $T_{a}$ air temperature, $\mathrm{RH}$ relative humidity, $\mathrm{SO}_{2}$ sulfur dioxide, $\mathrm{NO}_{2}$ nitrogen dioxide, $\mathrm{O}_{3}$ ozone, $P M_{10}$ particulate matter less than $10 \mu \mathrm{m}$ in diameter
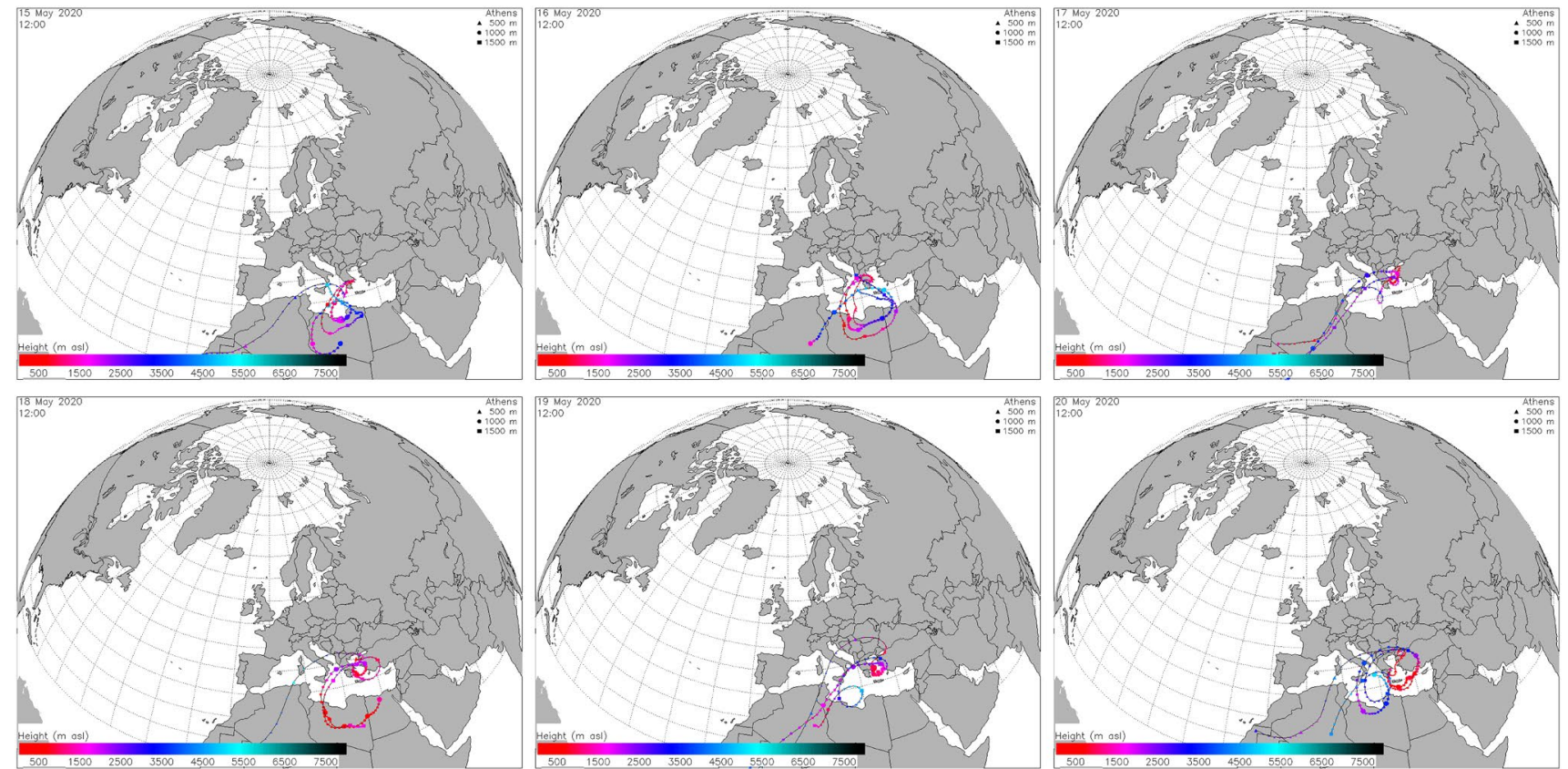

Fig. 4 Back trajectories of air masses for the period 15-20 May 2020 at 12 UTC. The trajectories were calculated using the FLEXTRA model and meteorological data were provided by the European Centre for Medium-Range Weather Forecasts (ECMWF)

poor air quality). The time evolutions of these two indices during this period took the form of a shock wave. Sudden large increases in DI and DAQI in a particular area can be lethal, as noted in previous studies, due to thermal shock in the general population and poor air quality (Pantavou et al. 2011; Theoharatos et al. 2010). 


\section{Conclusions}

This study showed an unusual and rapid increase in air temperature in the Thriasio Plain (Greece) that was indicative of an early spring heatwave, with the air temperature rising to more than $10{ }^{\circ} \mathrm{C}$ above the monthly average value for this region. Conditions of thermal discomfort were found to be positively correlated with poor air quality, mainly due to high levels of $\mathrm{PM}_{10}$ that may have been transported from the Sahara Desert. High ambient temperatures combined with high humidity and low air velocity (calm conditions) led to high thermal discomfort and contributed to poor air quality for a relatively long period of time.

Such episodes are not expected to persist in early spring, so the occurrence of this heatwave event should encourage authorities to plan precautionary measures for future events.

Acknowledgements The authors would like to thank Dr. Anastasios Christides (Bureau of Environment, Municipality of Elefsis) and Eleni Verouti MSc (Bureau of Environment, Municipality of Aspropyrgos) for providing meteorological and air pollutant data.

Funding There were no funding sources for this research.

\section{Compliance with ethical standards}

Conflict of interest The authors declare no conflict of interest.

\section{References}

Añel JA, Fernández-González M, Labandeira X, López-Otero X, De la Torre L (2017) Impact of cold waves and heat waves on the energy production sector. Atmosphere 8:209

Cecchini M, Zambon I, Pontrandolfi A, Turco R, Colantoni A, Mavrakis A, Salvati L (2019) Urban sprawl and the "olive" landscape: sustainable land management for "crisis" cities. GeoJournal 84(1):237-255

Flocas H, Kelessis A, Helmis C, Petrakakis M, Zoumakis M, Pappas K (2009) Synoptic and local scale atmospheric circulation associated with air pollution episodes in an urban Mediterranean area. Theoret Appl Climatol 95(3-4):265-277

Fontana G, Toreti A, Ceglar A, De Sanctis G (2015) Early heatwaves over Italy and their impacts on durum wheat yields. Nat Hazards Earth Syst Sci 15(7):1631-1637

Founda D (2020) The temperatures in May in Athens from the 19th century until today and the early heat of 2020. Kosmos Web Mag (Natl Observ Athens) 21 May 2020. http://magazine.noa.gr/archi ves/4018. Accessed 25 Aug 2020

Giles BD, Balafoutis CH, Maheras P (1990) Too hot for comfort: the heatwaves in Greece in 1987 and 1988. Int J Biometeorol 34:98-104

Hellenic National Meteorological Service (HNMS) (2020) Climate of Greece. http://www.hnms.gr/emy/el/climatology/climatology. Accessed 16 Nov 2020

Hellenic Statistical Authority (HSA) (2020) Demographic characteristics 2011. https://www.statistics.gr/. Accessed 10 Nov 2020
Ioannidis JPA, Axfors C, Contopoulos-Ioannidis DG (2020) Population-level COVID-19 mortality risk for non-elderly individuals overall and for non-elderly individuals without underlying diseases in pandemic epicenters. Environ Res 108:109890

Katsoulis BD, Kassomenos PA (2004) Assessment of the air-quality over urban areas by means of biometeorological indices: the case of Athens. Greece Environ Technol 25(11):1293-1304

Kottek M, Grieser J, Beck C, Rudolf B, Rubel F (2006) World Map of the Köppen-Geiger climate classification updated. Meteorol Z 15:259-263

Lykoudis S, Psounis N, Mavrakis A, Christides A (2008) Predicting photochemical pollution in an industrial area. Environ Monit Assess 142(1-3):279-288

Matzarakis A, Mayer H (1991) The extreme heatwave in Athens July 1987 from the point of view of human biometeorology. Atmos Environ 25B(2):203-211

Mavrakis A, Lykoudis S, Christides A, Dasaklis S, Tasopoulos A, Theoharatos G, Kyvelou S, Verouti E (2008) Air quality levels in a closed industrialized basin (Thriasion Plain, Greece). Fresenius Environ Bull 17(4):443-454

Mavrakis A, Papavasileiou C, Salvati L (2015) Towards (un)sustainable urban growth? Industrial development, land-use, soil depletion and climate aridity in a Greek agro-forest area. J Arid Environ $121: 1-6$

Mavrakis A, Rontos K, Chronopoulou C, Salvati L (2016) Population dynamics, industrial development and the decline of the traditional agro-forest landscape on the Mediterranean urban fringe: a case study in Greece. Int J Sustain Dev 19(1):1-14

Mavrakis A, Salvati L (2015) Analyzing the behaviour of selected risk indexes during the 2007 Greek forest fires. Int J Environ Res 9(3):831-840

Mavrakis A, Salvati L, Flocas H (2015) Mixing ratio as indicator of climate variations at a local scale: trends in an industrial area of the Eastern Mediterranean. Int J Climatol 36(3):1534-1538

Mavrakis A, Salvati L, Kyvelou S, Tasopoulos A, Christides A, Verouti E, Liakou M, Sirio C, Zambon I, Papavasileiou C (2020) Social contexts, local practices, and urban projects for a bioregional postcrisis recovery: the emblematic example of Athens' fringe, Greece. In: Fanfani D, Matarán Ruiz A (eds) Bioregional planning and design, volume II: issues and practices for a bioregional regeneration, part II: regional contexts, practices and projects for a bioregional recovery. Springer International, Cham, pp 119-140

Mavrakis A, Spanou A, Pantavou K, Katavoutas G, Theoharatos G, Christides A, Verouti E (2012) Biometeorological and air quality assessment in an industrialized area of eastern MediterraneanThriassion Plain, Greece. Int J Biometeorol 56(4):737-747

Mavrakis A, Tsiros I (2018) The abrupt increase in the Aegean Sea surface temperature during the June 2007 southeast Mediterranean heatwave - a marine heatwave event? Weather 74(6):201-207

McElroy S, Schwarz L, Green H, Corcos I, Guirguis K, Gershunov A, Benmarhnia T (2020) Defining heatwaves using sub-regional meteorological data to maximize benefits of early warning systems to population health. Sci Total Environ 721:137678

Metaxas DA, Kallos G (1980) Heatwaves from a synoptic point of view. Riv Meteorol Aeronau 2(2):107-119

Nava A, Shimabukuro JS, Chmura AA, Luz SLB (2017) The impact of global environmental changes on infectious disease emergence with a focus on risks for Brazil. ILAR J 58(3):393-400

Paliatsos AG, Nastos PTH (1999) Relation between air pollution episodes and discomfort index. Global Nest Int J 1:91-97

Pantavou K, Theoharatos G, Mavrakis A, Santamouris M (2011) Evaluating thermal comfort conditions and health responses during an extremely hot summer in Athens. Build Environ 46(2):339-344

Perkins-Kirkpatrick SE, Lewis SC (2020) Increasing trends in regional heatwaves. Nat Commun 11(1):1 
Sailor DJ, Baniassadi A, O’Lenick CR, Wilhelmi OV (2019) The growing threat of heat disasters. Environ Res Lett 14(5):054006

Stohl A (1998) Computation, accuracy and applications of trajectories-a review and bibliography. Atmos Environ 32:947-966

Theoharatos G, Pantavou K, Mavrakis A, Spanou A, Katavoutas G, Efstathiou P, Mpekas P, Asimakopoulos D (2010) Heatwaves observed in 2007 in Athens, Greece: synoptic conditions, bioclimatological assessment, air quality levels and health effects. Environ Res 110(2):152-161

Thom EC (1959) The discomfort index. Weatherwise 12:57-60

Toumpos M, Flocas HA, Christides A, Mavrakis A (2017) Generating a "typical air pollutant day" in Thriasio Plain, Greece. In:
Karacostas T, Bais A, Nastos P (eds) Perspectives on atmospheric sciences. Springer Atmospheric Sciences. Springer, Cham, pp $1081-1086$

Vougioukas S, Lagouvardos C, Dafis S (2020) Impressive temperature records from the heatwave of 15-19/05/2020. https://www.meteo .gr/article_view.cfm?entryID=1364. Accessed 1/10/2020.

Xia Y, Li Y, Guan D, Tinoco DM, Xia J, Yan Z, Yang J, Liu Q, Huo H (2018) Assessment of the economic impacts of heat waves: a case study of Nanjing, China. J Clean Prod 171:811-819

Xu Z, FitzGerald G, Guo Y, Jalaludin B, Tong S (2016) Impact of heatwave on mortality under different heatwave definitions: a systematic review and meta-analysis. Environ Int 89-90:193-203 